\title{
Matinya Pertunjukan Musik
}

\author{
Sang Nyoman Satria Irnanningrat \\ Mahasiswa S2 Penciptaan dan Pengkajian Seni, Institut Seni Indonesia Yogyakarta \\ E-mail: sangnyoman.satria@yahoo.com; HP:081906666714.
}

\begin{abstract}
Music is the work of sound art presented in the form of song, or composition, which expresses the writer's though and feeling through several music elements such as rhyme, melody, harmony, form and musical structure as well as expression as a wholeness. One of the way in expressing music is through music performance. However, by the development of technology, the musical performance becomes less enthused by the listeners. This study aims at identifying the forms of the death of music performance seen from McDonaldization and also to find the impacts of McDonaldization toward music performace. This study employs qualittive method of research and uses sociology as the approach of research. The results show that there are four dimensions of the form of the death of music performance; efficiency dimension, predictability dimension, calculability dimension, and control dimension. The next results shows that McDonaldization also brings impacts to the death of music performance, one of them is dehumanization.
\end{abstract}

Keywords: music; music performance; McDonaldization.

\begin{abstract}
Abstrak
Musik merupakan suatu hasil karya seni bunyi dalam bentuk lagu atau komposisi musik yang mengungkapkan pikiran dan perasaan penciptanya melalui unsur-unsur musik yaitu irama, melodi, harmoni, bentuk dan struktur musik serta ekspresi sebagai satu kesatuan. Salah satu cara penyampaian musik yaitu melaui pertunjukan musik. Namun, perkembangan teknologi membuat pertunjukan musik menjadi semakin jarang diminati oleh para penikmat musik. Tujuan dari penelitian ini adalah untuk mengetahui apa sajakah bentuk-bentuk penyebab matinya pertunjukan musik dilihat dari teori McDonaldisasi serta bagaimana efek McDonaldisasi terhadap pertunjukan musik. Penelitian ini menggunakan metode kualitatif serta menerapkan pendekatan sosiologi. Hasil dari penelitian ini menunjukkan bahwa terdapat empat dimensi dalam bentuk kematian pertunjukan musik yaitu dimensi efisiensi, dimensi prediksi, dimensi daya hitung, dan dimensi kontrol. Selanjutnya, McDonaldisasi juga membawa dampak terhadap matinya pertunjukan musik yaitu salah satunya adalah dehumanisasi atau manusia telah meninggalkan kodratnya sebagai manusia.
\end{abstract}

Kata kunci: musik; pertunjukan musik; McDonaldisasi.

\section{Pengantar}

Musik adalah cabang seni yang membahas dan menetapkan berbagai suara kedalam pola-pola yang dapat dimengerti dan dipahami manusia. Musik berasal dari kata muse, yaitu salah satu dewa dalam mitologi Yunani kuno bagi cabang seni dan ilmu; dewa seni dan ilmu pengetahuan. Musik yang baik adalah musik yang memiliki unsur-unsur melodi, ritme, dan harmoni (Banoe, 2003: 288).
Sedangkan definisi musik menurut Bernstein \& Picker (dalam Djohan, 2006: 36) adalah suara yang diorganisir kedalam waktu. Musik juga merupakan bentuk seni tingkat tinggi yang dapat mengakomodir interpretasi dan kreativitas individu. Sekelompok orang dalam kegiatan musik tidak pernah menunjukkan adanya dua orang yang mengekspresikan musik de-ngan cara yang mutlak sama.

Definisi tentang musik juga diungkapkan oleh Jamalus yang berpendapat 
bahwa musik adalah suatu hasil karya seni bunyi dalam bentuk lagu atau komposisi musik yang mengungkapkan pikiran dan perasaan penciptanya melalui unsur-unsur musik yaitu irama, melodi, harmoni, bentuk dan struktur lagu dan ekspresi sebagai satu kesatuan (dalam Muttaqin \& Kustap, 2008:3).

Dari beberapa pendapat diatas yang mendefinisikan tentang musik, kemudian dapat ditarik kesimpulkan bahwa musik adalah suatu hasil cipta manusia yang berisikan ide, pemikiran dan kreatifitas yang dituangkan menjadi karya seni bunyi dalam bentuk lagu atau komposisi musik yang memeliki unsur-unsur seperti irama, melodi, harmoni, bentuk, dan struktur lagu dan ekspresi sebagai satu kesatuan.

Dalam sejarah perkembangan musik, di masa lalu musik dikaitan dengan dua fungsi pokok, yaitu sebagai sarana nemesis Nemesis dari bahasa Yunani yang artinya transformasi dan imitasi dari luar ke dalam diri manusia. dan juga katarsis yang mengandung arti pemurnian jiwa melalui pengalaman emosional. Fungsi musik sebagai sarana nemesis dapat kita temukan dalam bentuk-bentuk pertunjukan oprera sekitar abad ke-16 di Eropa. Seorang penyanyi opera tidak hanya dituntut untuk menguasai teknik vokal dengan sangat baik, tetapi juga dituntut untuk menjiwai tokoh yang diperankannya. Jadi fungsi musik dalam opera adalah untuk merefleksikan emosi melalui kata-kata dan gerakan (Djohan, 2009: 86-87).

Fungsi musik sebagai sarana katarsis meyakini bahwa musik juga dapat menjadi sarana pengekspresian diri. Musik dianggap mempunyai kekuatan untuk menggugah emosi, yang dituangkan melalui penjiwaan terhadap alur cerita dan watak tokoh yang diperankan. Penjiwaan karakter dalam opera, misalnya akan terkait dengan berbagai macam ekspresi emosi yang tentu saja didukung oleh karya musik yang tepat seperti apakah pelaku sedang bermasalah, galau, ceria, percintaan dan lain sebagainya (87-88).

Tokoh Antropologi Allan P. Merriam dalam bukunya The Anthropology Of Music menyatakan terdapat 10 fungsi dari musik yaitu fungsi pengungkapan emosional, fungsi penghayatan estetis, fungsi hiburan, fungsi komunikasi, fungsi perlambangan, fungsi reaksi jasmani, fungsi yang berkaitan dengan norma sosial, fungsi kesinambungan budaya, dan fungsi pengintegrasian masyarakat. Oleh karena itu fungsi musik adalah hal-hal yang berkaitan dengan ide-ide maupun perilaku suatu masyarakat (Merriam, 1964: 32-33)

Musik merupakan salah satu jenis bentuk seni pertunjukan. Pertunjukan adalah seni yang disajikan dengan tampilan peragaan, yaitu seni akan dapat dinikmati dan dihayati selama berlangsungnya ungkapan oleh pelaku seni (Bastomi, 1988:42). Oleh karena itu pertunjukan musik adalah segala bentuk kreatifitas seorang atau sekelompok musisi yang dituangkan kedalam bentuk suatu pertunjukan yang dapat dipertontonkan kepada semua orang dalam bentuk seni musik sehingga ide, pemikiran, maupun kritik sosial yang musisi proyeksikan agar dapat dinikmati, diapresiasi, dan bermanfaat kepada orang banyak.

\section{Pembahasan}

\section{Pertunjukan Musik dan Perkembangan Teknologi}

Seiring berkembangnya kemajuan teknologi, hal ini memberi dampak negatif terhadap menurunnya minat masyarakat dalam menonton pertunjukan musik secara langsung. Penulis menemukan artikel yang berrjudul "Jangan Salahkan Teknologi" yang membahas tentang hadirnya "new technology" yang menyebabkan terpuruknya industri musik. Dalam sebuah diskusi yang diadakan di San Fransisco Music Tech Summit, seorang pembicara yang bernama David Lowery mempertanyakan apakah 
bisnis model digital yang baru akan lebih baik bagi para musisi (http://www.widiasmoro.com/2012/04/23/ja ngan-salahkan-teknologi/).

Dalam pandangannya, meskipun para artis musisi menjadwalkan tur dan roadshownya lebih banyak tahun ini dibandingkan dengan tahun-tahun sebelumnya namun rupanya minat orang yang datang ke tempat pertunjukan musik cenderung menurun. David Lowery mengatakan bahwa hadirnya Youtube dimana orang-orang dapat menonton pertunjukan musik tanpa harus bersusahpayah datang ke tempat konser diindikasikan merupakan salah satu faktor yang mempengaruhi turunnya minat seseorang menonton konser. Lebih lanjut David mengkritisi situs pencarian seperti Google yang telah menampilkan hasil pencarian berupa link ke situs ilegal. Meskipun Google juga telah menyediakan ruang pengaduan dengan DMCA, David memaparkan betapa mudahnya situs ini untuk diretas atau di crack. (http://www. widiasmoro.com/2012/04/23/jangansalahkan -teknologi/). Situs pencarian seper-ti Google juga merupakan salah satu faktor yang mempengaruhi menurunnya minat orang untuk menonton pertunjukan musik.

Selain Youtube dan situs pencarian google lainnya, faktor adanya perusahaan rekaman yang mencetak lagu berupa fisik dan digital seperti kaset, CD, DVD, dan saat ini berkembang ke teknologi digital, Soundcloud, RBT dan Apple dengan iTunes nya menyediakan aplikasi musik yang bisa mengunduh atau mendownload lagu secara online, juga membuat menurunnya apresiasi orang untuk datang menonton pertunjukan musik secara langsung.

Pada 2015 harian Kompas meng-adakan jajak pendapat mengenai minat orang dalam mendengarkan dan menonton pertunjukan musik. Dari 734 responden, 1\% mendengarkan musik melalui pemutar kaset atau $\mathrm{CD}, 62 \%$ mayoritas responden kelompok muda lebih terbiasa menikmati musik melalui internet dengan cara mengunduh maupun mendengarkan secara langsung atau streaming. Selain itu, sekitar 15\% lainnya mengakses melalui Youtube (http://print.kompas.com/baca/2016/01/05/In dustri-Mu-sik-Redup-oleh-Digital).

Hasil penelitian lainnya seperti, Global World Index menyimpulkan bahwa orangorang mendengarkan musik lewat internet meningkat hingga $76 \%$ selama periode 2012 2015. Data lain dari organisasi rekaman dunia Internasional Federation of Phonographic Industry (IFPI) mencatat $46 \%$ pendapatan industri musik secara global pada tahun 2014 sudah dikuasai rekaman musik digital. Sementara itu, rekaman musik fisik sebesar, $46 \%$ dan $8 \%$ sisanya dari pertunjukan langsung (http://www.ifpi.org/globalstatistics.php).

Dari data-data yang telah dipaparkan diatas, penulis mengindikasi akan terjadinya masalah di tahun-tahun yang akan datang terkait matinya pertunjukan musik secara langsung. Semakin canggihnya teknologi akan membuat orang menjadi malas untuk pergi menonton pertunjukan musik secara langsung. Selanjutnya, interaksi antara musisi dan fans secara langsung di gedung konser tidak akan dijumpai lagi. Ciri manusia sebagai mahluk sosial akan bertransformasi menjadi mahluk individu yang semua aktivitasnya mengandalkan kemajuan teknologi. Hal ini merupakan masalah yang sangat penting untuk diperhatikan. Oleh karena itu, penulis bermaksud untuk meneliti lebih lanjut mengenai matinya pertunjukan musik sebagai akibat dari perkembangan teknologi.

Berdasarkan gambaran yang telah dijelaskan dalam bab pendahuluan diatas, terdapat dua rumusan masalah dalam penelitian ini: yang pertama, apa ajakah bentuk-bentuk penyebab matinya pertunjukan musik dilihat dari teori McDonaldisasi, dan yang kedua yaitu 
bagaimana efek McDonaldisasiterhadap pertunjukan musik.

\section{Teori McDonaldisasi}

Dalam penulisan makalah ini, penulis menggunakan teori McDonaldisasi untuk mengatahui bagaimana proses terjadinya kematian pertunjukan musik dan bagaimana efek McDonaldisasi terhadap pertunjukan musik.

McDonaldisasi adalah teori yang dikemukakan oleh George Ritzer, seorang sosiolog dari universitas Maryland, menyatakan tentang suatu proses yang meliputi prinsip-prinsip atau dasar-dasar restauran cepat saji, mendominasi berbagai sektor didalam masyarakat dan seluruh dunia. Penyebaran McDonaldisasi meliputi bisnis restauran, pendidikan, dunia kerja dan periklanana (Ritzer, 1998: 1-3). McDonaldisasi itu sendiri merupakan sebuah sistem yang diterapkan oleh McDonald dalam proses sosial masyarakat modern. Dalam hal ini, Ritzer berpendapat bahwa McDonaldisasi adalah salah alat konsumsi baru selain alat-alat lainnya seperti mall, super store, kasino, saluran hiburan, dan lain sebagainya. Menurut Ritzer yang menggunakan acuan teori Max Weber, menemukan empat dimensi McDonaldisasi yaitu dimensi Efisiensi, Dimensi daya hitung, Dimensi prediksi, dan Dimensi kontrol (5).

Dimensi Efisiensi yaitu suatu teknik memilih sarana yang optimal untuk mendapatkan tujuan akhir yang telah ditetapkan (105). Dalam hal ini kata optimal bermakana suatu upaya mendapatkan dan memanfaatkan sarana sebaik dan sehemat mungkin. Proses Efisiensi ini dilakukan dengan cara menyederhanakan produk, yaitu dengan menggunakan sedikit bahan mentah, sederhana dalam pembuatan dan penyajiannya akan tetapi dapat dengan segera atau cepat dikonsumsi atau dinikmati konsumen. Dalam artian lain Efisiensi McDonaldisasi memaksa konsumen bekerja dan tidak dapat menikmati interaksi langsung (106).

Dimensi Prediksi, prinsip Prediksi ini dimaksudkan untuk mencapai kepastian dalam berbagai hal yang menyangkut berbagai aspek produksi, contohnya karyawan, mesin, dan waktu (108). Prinsip ini memberikan penyeragaman terhadap bahan mentah, penerapan teknologi, proses produksi, dan sitem pengepakan yang dimaksudkan untuk produksi massa (mass product). Pada akhirnya manusia tidak mempunyai ciri khasnya sendiri-sendiri karena identitasnya sudah diseragamkan oleh sistem McDonaldisasi.

Dimensi Daya hitung, dalam prinsipnya, McDonaldisasi lebih menekankan pada segala hal yang bisa dihitung atau dikalkulasi serta menitik beratkan pada kualitas dari pada kualitas (105). Penekankan pada kuantitas ini sangat berhubungan dengan proses untuk mencapai tujuan akhir. Dalam prosesnya lebih menekankan pada kecepatan, sedangkan pada hasil akhirnya lebih memfokuskan pada jumlah produksi atau keuntungan yang dapat dihasilkan. Tujuan akhir dari aplikasi prinsip daya hitung ini diharapkan dapat mempengaruhi keefisiensian karena segala sesuatu yang dapat dihitung akan mendukung prinsip efisiensi. Proses ini menciptakan ilustrasi kuantitas pada pemikiran konsumen dan mengatur proses produksi dan penyajian menjadi sesuatu yang dapat dikontrol untuk kepentingan penguasa. Mc-Donaldisasi berusaha untuk membuat bagaimana menyelesaikan dan menyajikan suatu produk dalam jumlah semaksimal mungkin dalam waktu yang sesingkat mungkin.

Dimensi Kontrol, dimensi ini menekankan pada penggantian sumber daya manusia dengan teknologi non manusia atau mesin untuk meningkatkan kontrol terhadap proses produksi, tenaga kerja, dan konsumen atau pelanggan (108). Penggunaan prinsip teknologi ini tidak hanya dilakukan dengan mesin-mesin atau peralatan, akan tetapi juga 
berbagai material, keahlian, pengetahuan, hukum, aturan, prosedur, serta tekniktekniknya (109).

\section{Analisis}

Dalam bagian analisis ini, penulis menemukan bahwa terdapat empat bentuk penyebab terjadi matinya pertunjukan musik berdasarkan teori McDonaldisasi yaitu efisiensi, prediksi, daya hitung, dan kontrol. Penjelasannya adalah sebagai berikut:

a. Bentuk-Bentuk McDonaldisasi Terha-dap Pertunjukan Musik

1) Dimensi Efisiensi

Ritzer menjelaskan tentang efisiensi dari McDonaldisasi sebagai suatu bentuk pengoptimalan untuk mendapatkan hasil yang telah ditetapkan. Dalam kasus matinya pertunjukan musik, teori efisiensi ini dapat dilihat dari munculnya industri perekaman musik yang mencetak lagu-lagu kedalam bentuk fisik seperti kaset, CD, dan DVD. Hal ini merupakan bentuk penghematan biaya, tenaga, dan waktu bagi para pelaku industri untuk dapat menghasilkan keuntungan yang sebesar-besarnya dengan cara yang seefisien mungkin jika dibandingkan dengan hasil laba atau keuntungan jika menyelenggarakan pertunjukan musik secara langsung yang akan membutuhkan banyak biaya.

Bentuk efisiensi lain dari pelaku industri musik yaitu para pelaku hanya perlu menyeleng- garakan satu kali proses pertunjukan musik dan atau mengadakan satu kali proses perekaman musik untuk kemudian dikemas dan dicetak kedalam bentuk media yang lebih sederhana seperti kaset, CD, dan DVD. Proses penyederhanaan ini tentu saja menghemat biaya. Contohnya seperti biaya tenaga kerja, misalkan jika dalam pertunjukan musik secara langsung diperlukan jumlah tenaga kerja atau crew yang terlibat dalam pementasan pertunjukan musik tentunya tidak sedikit dan memerlukan banyak biaya. Namun jika pertunjukan musik disederhanakan kedalam bentuk kaset, CD dan DVD dengan cara perekaman maka akan menghemat banyak biaya karena proses produksinya hampir sebagian besar dilakukan oleh mesin. Hal ini, sesuai dengan apa yang Ritzer jelaskan diatas mengenai proses efisiensi yang dilakukan dengan cara menyeder- hanakan produk industri, yaitu dengan menggunakan sedikit bahan mentah, sederhana dalam pembuatan dan penyajiannya akan tetapi dapat dengan segera atau cepat dikonsumsi atau dinikmati oleh konsumen.

Dengan adanya penyederhanaan produksi industri dari pertunjukan musik langsung kedalam bentuk kaset, CD, dan DVD maka para penikmat musik atau konsumen seolah-olah dapat menikmati pertunjukan musik melalui media tersebut diatas. Para konsumen tidak lagi dapat menikmati indahnya pertunjukan musik secara langsung karena merasa kenikmatan musik itu sendiri telah didapatkan melalui memutar media seperti kaset, CD, dan DVD. Hal ini dapat mengakibatkan kematian pada pertunjukan musik dikemudian hari karena para penikmat musik atau konsumen tidak lagi memerlukan pertunjukan musik sebagai bentuk hiburan, karena telah tergantikan dengan kemajuan teknologi.

\section{2) Dimensi Prediksi}

Prinsip Prediksi ini dimaksudkan untuk mencapai kepastian dalam berbagai hal yang menyangkut berbagai aspek seperti proses produksi, penerapan teknologi dan sitem pengepakan yang dimaksudkan untuk produksi massa (mass product). Proses McDonaldisasi dengan dimensi prediksi ini harus mengarah pada kesamaan mutu dan standar yang sengaja dibentuk oleh kaumkaum kapitalis. Dalam kasus matinya musik pertunjukan, kemajuan teknologi telah membuat keseragaman produk dan jenis yang diproduksi. Sejak diluncurkannya bentuk lagu-lagu yang dikemas dalam bentuk fisik seperti kaset, CD, dan VCD 
mereka para pengontrol modal dapat menghitung penjualan album para musisi dengan lebih mudah sekaligus bisa memprediksi hasil keuntungan dan calon konsumennya. Sistem ini sengaja dibuat agar lebih praktis dan efisien dalam hal biaya produksi dan pemasaran. Para pemilik modal tidak harus membuat para musisi secara rutin menyelenggarakan pertunjukan musik lagi. Cukup dengan mencetak lagulagu yang dikemas dalam bentuk fisik yang mengarah pada biaya yang efisien dan terprediksi seolah mempunyai muara yang sama, yakni pertunjukan musik tidak perlu lagi menghadirkan musisinya secara langsung. Penikmat musik cukup mendengarkan atau menonton di kaset, CD, dan VCD dan sudah memiliki kepuasan yang sama selayaknya menonton pertunjukan musik secara langsung.

Para pengontrol modal membuat keseragaman selera dengan cara menayangkan acara-acara musik yang nyaris sama. Contohnya tayangan dangdut yang rutin ditayangkan dibeberapa stasiun TV swasta. Dengan seringnya TV swasta menayangkan musik dangdut, masyarakat yang dulunya anti dangdut lama-lama akan familiar dan menyukai dangdut. Dengan semakin seringnya musik dangdut diperdengarkan ke publik akhirnya masyarakat tidak mempunyai ciri khasnya sendiri-sendiri karena identitasnya sudah disera-gamkan oleh sitem McDonaldisasi. Jadi bentuk prediksi dari McDonaldisasi ini membuat para pemikik modal dapat mengatur dan memprediksi hasil keuntungan, keseragaman selera, dan calon konsemennya.

\section{3) Dimensi Daya Hitung}

Dimensi daya hitung pada prinsipnya merupakan segala hal yang bisa dihitung. Proses McDonaldisasi dengan sistem daya hitung lebih menitikberatkan pada kuantitas dari pada kualitas. Selain itu sistem ini juga menekankan pada kecepatan hasil akhir jumlah produksi dan keuntungan yang sebanyak-banyaknya. Matinya musik pertunjukan sehubungan dengan majunya perkembangan tehnologi, salah satu faktor penyebabnya adanya industri perekaman musik yang mencetak lagu-lagu kedalam bentuk digital seperti iTunes.

Produk iTunes dihasilkan oleh salah satu dari produk perusahaan raksasa teknologi Apple. Dengan adanya layanan Aplikasi ini para penggunakan iPhone dapat membeli dan men-download musik dan produk digital lainnya dengan cepat dan mudah. Kemudahan ini dijadikan alasan bagi para pemilik modal bahwa iTunes telah memberikan kontribusi sebesar-besaran untuk keuntungan perusahaan. Sejak aplikasi ITunes di luncurkan, Apple telah menjual lebih dari 10 miliar lagu (http://www.plimbi. com/article/3154/ lebihdekat-dengan-itunes-pada-perangkat-

apple). Bentuk Daya Hitung inilah yang digunakan pemilik modal untuk mampu menghitung segala keuntungan dengan perhitungan yang telah dipersiapkan. Contohnya jika konsumen mengunduh satu lagu, maka mereka harus membayar Rp. 7.000; dan dikalikan dengan jumlah semua pengunduh seluruh dunia, maka hasilnya dapat dihitung sesuai dengan prediksi. Hal ini juga merupakan bentuk efisiensi dan prediksi yang ditunjang dengan bentuk daya hitung untuk mengukur seberapa besar keuntungan mereka.

Dengan adanya iTunes, para pemilik modal dapat menghitung beban biaya produksi mereka. Contohnya, dengan iTunes, para pemilik modal akan lebih menghemat biaya dari yang sebelumnya menggunakan bahan mentah seperti material kaset, CD, dan DVD, kini mereka tidak perlu lagi mengeluarkan beban biaya-biaya tersebut. Para konsumen cukup mengkoneksikan iphone atau gadget mereka dengan internet dan mengunduh lagu-lagu favorit mereka. Hal ini membuat pemilik modal dapat menghemat biaya produksi yang cukup signifikan dengan menggunakan tenknologi 
digital yang merupakan tujuan dari dimensi bentuk Daya Hitung dari McDonaldisasi.

\section{4) Dimensi Kontrol}

Dimensi ini menekankan pada penggantian sumber daya manusia dengan teknologi non manusia atau mesin untuk meningkatkan kontrol terhadap proses produksi. Pekerja manusia, betapapun terlatihnya mereka, pemilik modal tetap membutuhkan banyak biaya yang dikeluarkan untuk produksi. Misalnya membutuhkan musisi pengiring dalam proses rekaman musik. Saat ini seorang musisi tidak perlu lagi melibatkan banyak orang untuk penggarapan karya musiknya, dengan software musik seperti Cubase para musisi sudah mampu menghasilkan karya yang sesuai keinginannya. Betapapun terampilnya seorang musisi, meraka masih dapat membuat kesalahan yang akan memakan waktu yang lama dalam proses penggarapan karyanya. Untuk itu mengganti manusia dengan mesin ini menjanjikan kerja yang lebih terkontrol, efisien, dan cepat.

Dengan adanya dimensi Kontrol maka para pemilik modal dapat mengontrol biaya produksinya, baik yang berupa kontrol waktu, kontrol tenaga kerja, maupun kontrol selera. Kontrol waktu di sini berupa efisiensi waktu dalam proses produksi, contohnya pemilik modal akan memanfaatkan kecepatan menggu- nakan teknologi atau mesin dibandingkan dengan penggunaan sumber daya manusia atau tenaga kerja yang berpontensi melakukan kesalahan atau human error. Mesin akan lebih mengeliminir kesalahan yang terjadi dalam proses produksi. Hal ini juga merupakan deskripsi dari bentuk dimensi kontrol tenaga kerja yaitu mengurangi beban biaya produksi tenaga kerja yang digantikan dengan tenaga mesin. Selanjutnya untuk kontrol selera, para pemilik modal dapat menyeragamkan dan menstandari- sasi selera pasar, sehingga hasil penjualan dapat diprediksi dan dikontrol. Dalam hal ini, tujuan dari pemilik modal yaitu membuat para konsumen mempunyai selara dan standar yang sama; konsumen didoktrin untuk menyukai hal yang sama.

5. Efek McDonaldisasi Terhadap Pertunjukan Musik

Dengan adanya bentuk-bentuk McDonaldisasi yang berupa dimensi efisiensi, prediksi, daya hitung, dan kontrol membuat para pelaku industri musik, dalam hal ini para pemilik modal, dapat dengan mudah mendapatkan keuntungan sebesar-besarnya dan menghemat berbagai biaya-biaya proses produksi. Efek yang dihasilkan dari dimensidimensi McDonaldisasi ini yaitu membuat konsumen, dalam hal ini manusia, tidak lagi dapat berinteraksi dengan sesama manusia karena lebih banyak menghabiskan waktu mereka dengan teknologi. Contohnya dalam segi efisiensi, manusia merasa dengan adanya industri perekaman yang dikemas dalam bentuk fisik seperti; kaset, CD, dan DVD yang kemudian dikembangkan kedalam bentuk digital seperti; Youtube, RBT, dan iTunes mereka seolah-olah sudah mendapatkan kepuasan yang sama selayaknya menonton pertunjukan musik secara langsung. Hal ini menjadi efek irrasionalisasi karena manusia tidak dapat berfikir bahwa kemajuan teknologi berupa kaset dan sebagainya merupakan topeng dari para pemilik modal untuk menghemat biaya produksi mereka.

Selanjutnya untuk dimensi prediksi, manusia menjadi target dari pemilik modal guna mendapatkan keuntungan. Sedangkan untuk dimensi daya hitung dan kontrol, manusia menjadi sasaran para pemilik modal untuk menerapkan idealisme mereka tentang standarisasi dan penyeragaman selera secara massal. Hal ini membuat manusia kehilangan akal atau rasional mereka karena dimensi atau bentuk-bentuk McDonaldisasi sejatinya mengontrol pola pikir, perilaku, kegiatan serta selera mereka dalam kehidupan sehari-hari. 
Efek irrasionalisasi ini membuat manusia kehilangan interaksi dengan manusia yang lain. Contohnya manusia tidak lagi menonton pertunjukkan musik yang dipertunjukkan manusia secara langsung, dan digantikan oleh mesin berupa kaset, CD, VCD, Youtube, RBT, dan iTunes. Hal yang sama juga terjadi pada para musisi yang akhirnya tidak mampu berinteraksi lagi dengan penggemarnya karena karya mereka sudah tidak diperdengarkan lagi secara langsung, maka matilah pertunjukkan musik mereka. Dampak terburuk dari McDonaldisasi ini adalah manusia saat ini dan pada akhirnya dikhawatirkan akan kehilangan fungsi dan sifat manusia. Dengan kata lain seperti yang disebutkan oleh Ritzer bahwa McDonaldisasi dapat berperan sebagai proses dehumanization dalam kehidupan masyarakat.

\section{Penutup}

Bentuk McDonaldisasi seperti efisiensi, prediksi, daya hitung, dan kontrol yaitu merupakan sistem yang diciptakan oleh kaum kapitalis untuk dapat menguasai pasar dan menciptakan standarisasi atau penyeragaman berupa penyeragaman produk, selera, serta membentuk kebiasaan dan perilaku konsumen untuk mengikuti kontrol para pemilik modal. Contohnya dengan mendengarkan musik melalui kaset, CD, DCD, Youtube, dan iTunes, para konsumen sejatinya dijauhkan dengan nilainilai kemanusiaan itu sendiri dengan dalih efisien, praktis, maupun atas nama modernitas.

Dengan perilaku dan kebiasaan mendengarkan musik lewat media-media seperti yang telah disebutkan di atas, maka pertunjukkan musik akan mati. Interaksi di antara musisi dengan penggemarnya akan mati karena penggemar akhirnya sudah tidak akan menonton pertunjukkan secara langsung. Senada dengan itu para musisipun juga tidak akan lagi dapat berinteraksi dengan para penggemarnya secara langsung karena karya-karya mereka sudah tersedia dalam format kaset, CD, DVD, Youtube dan iTunes. Oleh karena itu, kita buktikan dalam beberapa tahun mendatang apakah teori McDoaldisasi ini terbukti atau tidak dalam segi pentunjukan musik dengan melihat berbagai fenomena saat ini yang manusia sudah kehilangan sifat atau nature manusia itu sendiri yang akan mengarah pada dehumanisasi.

\section{Referensi}

1. Buku dan Jurnal

Banoe, Pono. 2003. Kamus Musik. Yogyakarta: Kanisius.

Bastomi, S. 1988. Apresiasi Kesenian Tradisional. Semarang: IKIP Semarang Press.

Djohan. 2006. Terapi Musik: Teori dan Aplikasi. Yogyakarta. Galangpress.

. 2009. Psikologi Musik. Yogyakarta: Best Publisher.

Kustap, Muttaqin. 2008. Seni Musik Klasik Jilid

2. Jakarta: Direktorat Pembinaan Sekolah Kejuruan.

Merriam, Alan P. 1964. The Anthropology of Music. Chicago Nortwestern University. Ritzer, George. 1998. The McDonaldization Thesis. Thousand Oaks, CA: SAGE.

\section{Webtografi}

http://www.widiasmoro.com/2012/04/23/jan gan-salahkan-teknologi/, diakses pada tanggal 5 Juni 2016 pukul 18.19 WIB. http://print.kompas.com/baca/2016/01/05/In dustri-Musik-Redup-oleh-Digital, diakses pada tanggal 5 Juni 2016 pukul 20.40 WIB.

http://www.ifpi.org/global-statistics.php, diakses pada tanggal 7 Juni 2016 pukul 18.30 WIB.

http://www.plimbi.com/article/3154/lebihdekat-dengan-itunes-pada-perangkatapple, diakses pada tanggal 9 juni 2016 pukul 18.05 
Promusika

ISSN: 2338-039007
Volume 4, Nomor 2, Oktober 2016

pp. 94-101 